\title{
The Performance of Serum Cortisol, Plasma Corticotropin and Serum Dehydroepiandrosterone Sulfate Levels in the Diagnosis of Hypothalamic Pituitary Adrenal Dysfunction
}

\section{Abstract}

Background: There is no single test can identify hypothalamic-pituitary-adrenal dysfunction (HPAD) perfectly. The study aimed to assess the performance of measuring serum cortisol, serum dehydroepiandrosterone sulfate (DHEA-S) and plasma corticotropin (ACTH) in comparison with standard-dose short cosyntropin $(250 \mu \mathrm{g})$ testing for the diagnosis of HPAD.

Methods: This is a cross-sectional study from Al-Faiha Specialized Diabetes, Endocrine, and Metabolism Center (FDEMC) in Basrah for the period of November 2014 to October 2015. For all patients with suspected HPAD; baseline serum cortisol, serum DHEA-S and plasma $\mathrm{ACTH}$ and were measured, followed by a formal short cosyntropin test as the gold standard test.

Results: The total number of the study participant was 169 patients. Of them, 134 (79.3\%) were women. Their age ranges from 5-80 years. The cut-off serum cortisol that predicts abnormal short cosyntropin test was less than $5.31 \mu \mathrm{g} / \mathrm{dl}$ with maximal sensitivity and specificity of $87.7 \%$ and $90.4 \%$ respectively. The cut-off serum DHEA-S that predict abnormal short cosyntropin test was less than $31.11 \mu \mathrm{g} / \mathrm{dl}$ with a sensitivity of $89.2 \%$ and specificity of $62.7 \%$. The least reliable parameter to predict the abnormal short cosyntropin was the plasma ACTH level with a cut-off of less than $5.30 \mathrm{pg} / \mathrm{ml}$ and lowest sensitivity of $68.8 \%$ and specificity of $74.5 \%$.

Conclusion: To exclude HPAD, serum cortisol at 9-11 am having the highest predictive value, DHEA-S has the midway function and plasma
Ali Hussein Ali Alhamza1, Abbas Ali Mansour², Nazar S. Haddad ${ }^{3}$

1 Endocrinolgist, Al-Faiha Specialized Diabetes, Endocrine, and Metabolism Center (FDEMC), Basrah, Iraq.

2 Professor Diabetes, Endocrine and Metabolism Division. Department of Medicine. Basrah College of Medicine, Basrah, Iraq.

3 Ass. Prof. in Chemical Pathology. Department of Biochemistry. Basrah College of Medicine, Basrah, Iraq.

Contact information:

Abbas Ali Mansour.

Address: Hattin post office. P.O Box: 142, Basrah - 61013.

Tel: 009647801403706.

”ambaam@gmail.com 
ACTH is the least reliable for that. Combination of serum cortisol and serum DHEA-S yield the best performance for combinations of test.

\section{Keywords}

Hypothalamic Pituitaryadrenal Dysfunction; Short Cosyntropin Test;

Dehydroepiandrosterone Sulfate; Corticotropin; Cortisol.

The diagnosis of adrenal insufficiency (Al) is a challenging task, and the lack of awareness of this disease lead to serious consequences, hence untreated $\mathrm{Al}$ associated with increase in mortality and morbidity. [1] Adrenocorticotropin (ACTH) hormone handle the function of inner two layers of adrenal gland cortex zona glomerulosa and zona reticularis that secrets glucocorticoid and adrenal androgens respectively. [2] Corticotrophin releasing hormone $(\mathrm{CRH})$ is a peptide hormone secreted from hypothalamus, responsible for secretion of ACTH from pituitary gland. [3] Based on that measurement of plasma ACTH is helpful to differentiate primary and secondary Al. Cortisol and ACTH follow circadian rhythm, cortisol peak in the early morning from 6-8 am. [4] However; early morning basal cortisol used in clinical practice to diagnose Al. Serum cortisol level below $1.8 \mu / \mathrm{dl}$ or above $18 \mu / \mathrm{dl}$ confirm and exclude Al respectively. [5]

Adrenal androgens androstenedione,dehydroepi androsterone and dehydroepiandrosterone sulphate (DHEA-S) in particular DHEA-S less affected by circadian rhythm and has a long half-life reach 10 20 hours. [6] Normal age and sex specific DHEA$S$ has sensitivity of $100 \%$ to exclude HPAD. [7] Plasma ACTH less commonly use in clinical practice to diagnose secondary Al because it is normal or lag behind suppression of cortisol and DHEA-S. [8] Dynamic tests remain the best way to diagnose endocrine diseases. In Al, insulin tolerance test or called insulin induced hypoglycemia is gold standard because of unsafe it is prohibited now a days. [9] The most common and currently used to evaluate Hypothalamic-pituitary-adrenal (HPA) axis dysfunction is short cosyntropin test, it has a shortcomings in the performance that stand clearly from specificity and sensitivity analysis which is as low as 57\%-79\%. [10-11] Searching for other methods to diagnose HPA integrity that have high specificity and sensitivity are needed.

\section{The Aim of the study}

Was to assess the performance of measuring serum cortisol, serum DHEA-S and plasma ACTH in comparison with standard-dose short cosyntropin (250 $\mu \mathrm{g}$ ) testing for diagnosis of HPAD.

\section{Patients and methods}

\section{Setting, and Participants}

Participants in this cross-sectional study were the patients selected from Al-Faiha Specialized Diabetes, Endocrine, and Metabolism Center (FDEMC), in Basrah for the period of November 2014 to October 2015.

Subject Inclusionary criteria included ambulatory patients with a suspicious diagnosis with HPAD.

\section{Inclusion criteria}

All patients with suspicion of secondary Al, in particular, those patients with exogenous steroid exposure. 


\section{Exclusion Criteria}

- Patients referred from Intensive Care Unit (ICU).

- Currently on glucocorticosteroid therapy replacement in the preceding one week.

- Pregnant women, and those who use an oral contraceptive pills or hormone replacement therapy in the preceding six weeks.

- Those on drugs affect cortisol metabolisms like spironolactone, and antiepileptic drugs.

- Primary Al (Addison's disease).

All subjects provided verbal informed consent, and the ethical committee of the Basrah College of Medicine approved the research protocol.

\section{Principle of the Biochemical tests}

All patients given instructions one day before the procedure and fasting state was not necessary. The procedure time was from 9:00-11:00 am. From all patients $10 \mathrm{ml}$ of blood withdrawn for baseline cortisol, ACTH and DHEA-S. All blood samples used were serum except ACTH; it is measured in plasma. This is followed by intramuscular injection of $250-\mu \mathrm{g}$ cosyntropin, and cortisol levels measured at 0.30 , and 60 minutes. The normal adrenal reserve response is a cortisol value greater than $20 \mu \mathrm{g} / \mathrm{dL}$ (555 nmol/L) at any time 30 , or 60 minutes or both.

\section{Research Instruments}

The plasma ACTH, serumcortisol, serum DHEA-S, were measured using electrochemiluminescence immunoassay (ECLA) by cobas e 411 (Roche Diagnostics, Germany) analyzer using manufacturersupplied reagents and instructions.

For $\mathrm{ACTH}$, the measuring range was $1.0-2000$ $\mathrm{pg} / \mathrm{ml}$ and specified the intra-assay precision of $5-100 \mathrm{pg} / \mathrm{ml}(<5 \% \mathrm{CV})$. While cortisol, the measuring range was $0.018-63.4 \mu \mathrm{g} / \mathrm{dl}$ and specified the intra-assayprecision of $>110 \mathrm{nmol} / \mathrm{l}(<6 \% \mathrm{CV})$.

DHEA-S measuring range was $0.100-1000 \mu \mathrm{g} / \mathrm{dl}$ and specified the intra-assay precision of $50-1000$ $\mu \mathrm{g} / \mathrm{dl}(<5 \% \mathrm{CV})$.

\section{Normal reference interval}

Plasma ACTH ranges from 7-66 pg/ml according to kit value.

DHEA-S, serum according to Mayo Clinic medical laboratories, reference interval according to age and gender. [12]

\section{Statistical analysis}

Data analysis was done using SPSS 15 (SPSS Inc, Chicago, IL, USA). Continuous variables plotted as the mean (SEM). Categorical variables plotted as a percentage.

The area under the receiver-operating characteristics (ROC) curves used to assess the diagnostic performance of each of the three parameters; plasma ACTH Level, serum DHEA-S, and serum cortisol together with combinations of parameters of abnormal cortisol and ACTH (Panel I), abnormal DHEA-S and ACTH (Panel II), abnormal cortisol and DHEA-S (Panel III), and abnormal cortisol, DHEA-S and ACTH (Panel IV) to predict the abnormal short cosyntropin test.

The cut-off plasma ACTH Level, serum DHEA-S, and serum cortisol value was calculated by plottingthe true positive rate (sensitivity) against the false positive rate (1-specificity).

\section{Results}

The cause of HPAD in our patients was the exogenous use of glucocorticosteroid in almost most of the patients or with symptoms of adrenal dysfunction without a history of drug use. None of the our study sample,were having a pituitary tumor, surgery, or radiation before.

Total number of the study participants was 169 patients (Table 1) of them 134 (79.3\%) were women. Their ages range from 5-80 years. The majority, 131 patients $(77.5 \%)$ were in the age range 21-50 years, the mean age is mean \pm SEM age $38.8 \pm 0.94$ years. Forty point eight percent were having suppressed ACTH, and $59.2 \%$ had a level 
Table 1. Patients' characteristics.

\begin{tabular}{|l|c|c|}
\hline Male & & No (\%) \\
\hline Female & & $35(20.7)$ \\
\hline Age(year) range 21-50 & (Mean \pm SEM) & $38(79.3)$ \\
\hline DHEA-S & Normal & $71(42.0)$ \\
\hline Cortisol & Low & $96(56.8)$ \\
\hline ACTH & Missing & $2(1.2)$ \\
\hline \multirow{2}{*}{ Short cosyntropin test } & Normal & $102(60.3)$ \\
\hline & Low & $67(39.7)$ \\
\hline & Normal & $69(40.8)$ \\
\hline
\end{tabular}

Table 2. Sensitivity and specificity of plasma ACTH of the short cosyntropin test.

\begin{tabular}{|c|c|c|c|c|c|}
\hline \multicolumn{6}{|c|}{ Short cosyntropin test } \\
\hline \multirow{3}{*}{$\begin{array}{l}\text { Plasma } \\
\text { ACTH } \\
\text { Level }\end{array}$} & & $\begin{array}{l}\text { Abnormal } \\
\text { Response }\end{array}$ & $\begin{array}{l}\text { Normal } \\
\text { response }\end{array}$ & & \\
\hline & Low & 43 & 26 & $62.9 \%$ & $\begin{array}{l}\text { Positive } \\
\text { predictive } \\
\text { value }\end{array}$ \\
\hline & Normal & 22 & 78 & $79.2 \%$ & $\begin{array}{l}\text { Negative } \\
\text { predictive } \\
\text { value }\end{array}$ \\
\hline & & $68.8 \%$ & $74.5 \%$ & & \\
\hline & & Sensitivity & Specificity & & \\
\hline Total & & 65 & 104 & & \\
\hline
\end{tabular}

Table 3. Sensitivity and specificity of serum DHEA-S to short cosyntropin test.

\begin{tabular}{|c|c|c|c|c|c|}
\hline \multicolumn{6}{|c|}{ Short cosyntropin test } \\
\hline \multirow{3}{*}{$\begin{array}{l}\text { Serum } \\
\text { DHEA-S } \\
\text { Level }\end{array}$} & \multirow{3}{*}{$\begin{array}{l}\text { Low } \\
\text { Normal }\end{array}$} & $\begin{array}{l}\text { Abnormal } \\
\text { Response }\end{array}$ & $\begin{array}{l}\text { Normal } \\
\text { response }\end{array}$ & & \multirow[b]{2}{*}{$\begin{array}{l}\text { Positive } \\
\text { predictive } \\
\text { value }\end{array}$} \\
\hline & & 58 & 38 & $60.4 \%$ & \\
\hline & & 7 & 64 & $90.1 \%$ & $\begin{array}{l}\text { Negative } \\
\text { predictive } \\
\text { value }\end{array}$ \\
\hline & & $89.2 \%$ & $62.7 \%$ & & \\
\hline & & Sensitivity & Specificity & & \\
\hline Total & & 65 & 102 & & \\
\hline
\end{tabular}

in the reference range. The mean $\pm \mathrm{SEM}$ for $\mathrm{ACTH}$ level was $28.6 \pm 11.8 \mathrm{pg} / \mathrm{ml}$. Mean \pm SEM of DHEA-S was $75.36 \pm 8.6 \mu / \mathrm{dl}$; it was low in $56.8 \%$. For basal serum cortisol, the mean \pm SEM was $9.7 \pm 0.857 \mu \mathrm{gdl}$. It was low in $39.7 \%$. Results of the short cosyntropin test were abnormal in 56 patients (38.5\%).

The sensitivity,specificity, positive predictive values and negative predictive values of all parameters (plasma ACTH Level, serum DHEA-S and serum cortisol) alone in comparison with the standard test, the short cosyntropin test are presented in (Table 2).

The sensitivity of plasma ACTH Level was $68.8 \%$, specificity $74.5 \%$, positive predictive values $62.9 \%$ and negative predictive value $79.2 \%$. This mean that the false positive rate was $25.5 \%$, a false negative rate $31.2 \%$, positive likelihood ratio equal to 2.92 and negative likelihood ratio equal to 0.418 .

The sensitivity of serum DHEA-S was $89.2 \%$, specificity $62.7 \%$, positive predictive values $60.4 \%$ and negative predictive value $90.1 \%$. This means that the false positive rate was $37.3 \%$, a false negative rate $10.8 \%$, positive likelihood ratio equal to 2.39 and negative likelihood ratio equal to 0.172 . (Table 3)

Level of serum cortisol (Table 4) (Figure 1) had a sensitivity of $87.7 \%$, specificity $90.4 \%$, positive predictive values $85.1 \%$ and negative predictive value

Table 4. Sensitivity and specificity of serum cortisol of short cosyntropin test.

\begin{tabular}{|c|c|c|c|c|c|}
\hline \multicolumn{6}{|c|}{ Short cosyntropin test } \\
\hline \multirow{3}{*}{$\begin{array}{l}\text { Serum } \\
\text { Cortisol } \\
\text { Level }\end{array}$} & & $\begin{array}{l}\text { Abnormal } \\
\text { Response }\end{array}$ & $\begin{array}{l}\text { Normal } \\
\text { response }\end{array}$ & & \multirow[b]{2}{*}{$\begin{array}{l}\text { Positive } \\
\text { predictive } \\
\text { value }\end{array}$} \\
\hline & Low & 57 & 10 & $85.1 \%$ & \\
\hline & Normal & 8 & 94 & $92.2 \%$ & $\begin{array}{l}\text { Negative } \\
\text { predictive } \\
\text { value }\end{array}$ \\
\hline & & $87.7 \%$ & $90.4 \%$ & & \\
\hline & & Sensitivity & Specificity & & \\
\hline Total & & 65 & 104 & & \\
\hline
\end{tabular}




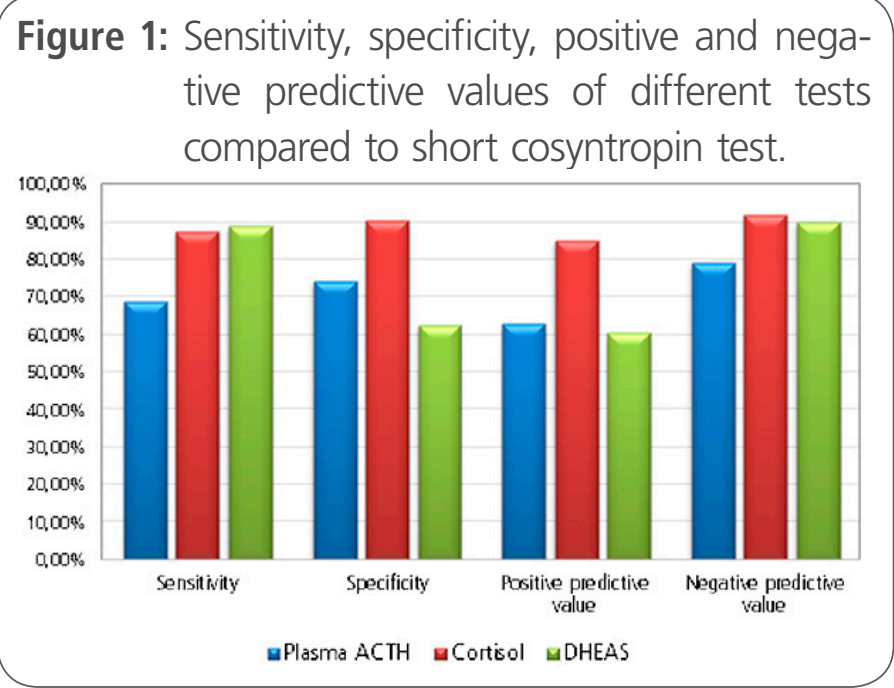

Table 5. Cut-off values of serum cortisol, DHEA-S and plasma $\mathrm{ACTH}$ and their predictive performance that indicate abnormal short.

\begin{tabular}{|c|c|c|c|c|}
\hline & $\begin{array}{c}\text { The area } \\
\text { under } \mathrm{ROC} \\
\text { curve }(95 \% \mathrm{CI})\end{array}$ & Cut-off & Sensitivity & Specificity \\
\hline $\begin{array}{l}\text { Plasma } \\
\text { ACTH }\end{array}$ & $\begin{array}{c}0.762 \\
(0.679-0.834)\end{array}$ & $5.30 \mathrm{pg} / \mathrm{ml}$ & $68.8 \%$ & $74.5 \%$ \\
\hline $\begin{array}{l}\text { Serum } \\
\text { DHEA-S }\end{array}$ & $\begin{array}{c}0.887 \\
(0.829-0.936)\end{array}$ & $31.11 \mu \mathrm{g} / \mathrm{dl}$ & $89.2 \%$ & $62.7 \%$ \\
\hline $\begin{array}{l}\text { Serum } \\
\text { cortisol }\end{array}$ & $\begin{array}{c}0.941 \\
(0.903-0.979)\end{array}$ & $5.31 \mu \mathrm{g} / \mathrm{dl}$ & $87.7 \%$ & $90.4 \%$ \\
\hline $\begin{array}{l}\text { Abnormal } \\
\text { Cortisol } \\
\text { and ACTH } \\
\text { (Panel I) }\end{array}$ & $\begin{array}{c}0.775 \\
(0.696-0.855)\end{array}$ & - & $60.0 \%$ & $95.1 \%$ \\
\hline $\begin{array}{l}\text { Abnormal } \\
\text { DHEA-S } \\
\text { and ACTH } \\
\text { (Panel II) }\end{array}$ & $\begin{array}{c}0.776 \\
(0.697-0.855)\end{array}$ & - & $63.1 \%$ & $92.2 \%$ \\
\hline $\begin{array}{l}\text { Abnormal } \\
\text { cortisol } \\
\text { and } \\
\text { DHEA-S } \\
\text { (Panel III) }\end{array}$ & $\begin{array}{c}0.916 \\
(0.863-0.969)\end{array}$ & - & $86.2 \%$ & $97.1 \%$ \\
\hline $\begin{array}{l}\text { Abnormal } \\
\text { cortisol, } \\
\text { DHEA-S } \\
\text { and ACTH } \\
\text { (Panel IV) }\end{array}$ & $\begin{array}{c}0.795 \\
(0.717-0.873)\end{array}$ & - & $60.0 \%$ & $99.0 \%$ \\
\hline
\end{tabular}

$92.2 \%$. This means that the false positive rate was $9.6 \%$, a false negative rate $12.3 \%$, positive likelihood ratio equal to 9.13 and negative likelihood ratio equal to 0.136 .

The cut-off point of serum cortisol that predicts abnormal short cosyntropin test was less than $5.31 \mu \mathrm{g} / \mathrm{dl}$ of maximal sensitivity and specificity of $87.7 \%$ and $90.4 \%$ respectively (Table 5 ). The cut-off point of serum DHEA-S that predict abnormal short cosyntropin test was less than 31.11 $\mu \mathrm{g} / \mathrm{dl}$ with a sensitivity of $89.2 \%$ and specificity of $62.7 \%$. The least reliable parameter to predict the abnormal short cosyntropin was the plasma ACTH level with a cut-off of less than $5.30 \mathrm{pg} / \mathrm{ml}$ and lowest sensitivity of $68.8 \%$ and specificity of $74.5 \%$.

Performance of baseline parameters in comparison with cosyntropin test results is presented in Table 5. Highest Specificity and sensitivity for HPAD were seen with dual basal morning serum cortisol, and serum DHEA-S were it reaches for $86.2 \%$ and $97.1 \%$, respectively. The only comparable to that was basal morning cortisol with specificity and sensitivity of $87.7 \%$ and $90.4 \%$, respectively. The combination of abnormal all parameters of serum cortisol, serum DHEA-S, and plasma ACTH will improve the specificity to $99 \%$, but reduced the sensitivity to very low level (60.0\%).

The use of a panel of tests combination to improve the performance of predicting abnormal short cosyntropin test yield that, a combination of morning serum cortisol and serum DHEA-S will have the best performance.

\section{Discussion}

Glucocorticosteroids nonprescription use is not rare in Iraq for years. This makes the risk of HPAD prevalence very high, especially with denial of use. [13]

The availability of short cosyntropin test can not guarantee always, and the insulin stress test is dangerous in our locality. [14] 
For that reason, we tried to have a panel of simple tests which are feasible and available to assess the risk of HPAD, which can be fatal if missed. [15-16]

A majority of HPAD seen in our Center is due to use of exogenous corticosteroids for various reasons, but most of them are due to nonprescription use. [13] This is established fact, all over the world. [16]

Adrenal insufficiency after discontinuation of glucocorticoid occurs frequently; there is no administration form, dosing, treatment duration, or underlying disease for which adrenal insufficiency it can be excluded with certainty. [17]

More than two third of patients in this study were women in the age range 21-50. Similar finding seen from the same Center before, where women constituted $69 \%$ of those self-prescribed corticosteroids. [13] In a study by Hahner et al., women to men ratio for secondary Al were 113:77 with median age of 59 years. [18] The female predominance for HPAD is due to more use of corticosteroids in our patients that difficult to explain.

The best performance seen in this study was for serum cortisol from 9-11 am with the morning serum cortisol of $<5.31 \mu \mathrm{g} / \mathrm{dl}$ goes with the diagnosis of HPAD. Others advocate that serum cortisol $\leq 5 \mu \mathrm{g} / \mathrm{dL}$ to confirm HPAD. [5, 10-11, 19]

In children some suggested that un-stimulated serum cortisol $<3.9 \mu \mathrm{g} / \mathrm{dL}$ is mandatory for the diagnosis of HPAD, if used alone with morning cortisol $>13.8 \mu \mathrm{g} / \mathrm{dl}$ goes with normal function and they advised doing dynamic stimulation tests only for those with morning cortisol between 3.9-13.8 $\mu \mathrm{g} / \mathrm{dl}$. [20]

The performance of DHEA-S was medium in between. One study found that normal age and gender-specific value of DHEA-S exclude HPAD in $100 \%$. [6] It's had been found that serum DHEA-S fall even before the serum cortisol in those with a history of exogenous use of glucocorticosteroid and lasted up to one year after drug stoppage, which is the case in our study. [6]
Serum DHEA-S used as screening test to diagnose HPAD are advocated. [16] However; DHEA-S if not enough for diagnosis, and low values need to be confirmed by other tests for adrenal function. [5] DHEA-S could not differentiate between primary or secondary adrenal failure and low DHEA-S also found after post-traumatic stress disorder and depressive symptoms. [21]

The worst performance was plasma ACTH in this study. This result proved before, where it is useful in the diagnosis of primary Al. [17] This can be explained on the basis, that cortisol derangement in HPAD could be due to an ACTH-independent mechanism, one of which reduce exertion and metabolism of cortisol by the liver and kidney that coined the term relative insufficiency of the hypothalamic-pituitaryadrenal axis. [22-25] These mechanisms could increase cortisol during stress and save human life, but stress last for more than a week would affect the affect the adrenocortical integrity and function. [26]

Furthermore, reduced response to exogenous corticotropin could be due to reduce adrenocortical ACTH signaling that affects the results of dynamic tests to diagnose the HPAD. That's why the short cosyntropin test carries poor sensitivity, which can be a wide range (57\%-79\%). [17] Nevertheless, the normal short cosyntropin test confirms more normality of the HPA axis. [27]

The HPAD is usually characteristically partial due to partial secretion of $\mathrm{CRH}$ and or ACTH. [11] For that reason, the diagnosis of the HPAD is quite challenging for the most endocrinologist. Patients with partial nature of ACTH deficiency will have a noload response to short cosyntropin test, especially if the cut-off point of cortisol will be $18.1 \mu \mathrm{g} / \mathrm{dl}$ and below, so cut-off of $20 \mu \mathrm{g} / \mathrm{dl}$ will improve the sensitivity of the test. [6]

The use of a panel of two tests to predict HPAD was explored in this study where the combination of morning serum cortisol and serum DHEA-S gave the best results to predict dysfunction. This was esta- 
blished recommendation by some endocrinologist. [5] The use of three panels of tests involving serum cortisol, serumDHEA-S, and plasma ACTH will have the best specificity, but very poor sensitivity. This finding is not explored before. [5]

The potential application of this study is that DHEA-S used as a tool to diagnose hypothalamic pituitary adrenal dysfunction in the afternoon because DHEA-S not subjected to circadian rhythm due to prolonged half-life. [11, 20, 21, 26-28] Since the majority of HPAD will present at afternoon to the emergency units or hospitals were the short cosyntropin not feasible and serum cortisol, and plasma ACTH will become unreliable.

\section{Study limitation}

the gold standard test in this study was a short cosyntropin test and not the insulin stress test. Because the insulin stress test carries many dangers. $[15,29]$ And, DHEA-S cut-off we used was regardless the age and gender. Furthermore, measurements of serum DHEA levels during the short cosyntropin test would add more benefit in the interpretation of short cosyntropin test with the improvement of diagnostic accuracy. [8]

\section{Conclusion}

To exclude HPAD, serum cortisol at 9-11 have the highest predictive value, DHEA-s has the midway function, and plasma ACTH is the least reliable for that. The combination of serum cortisol and serum DHEA-s yield the best performance for combinations of the combinations of the test

\section{References}

1. Nicolaides NC, Charmandari E, Chrousos GP, Kino T. Circadian endocrine rhythms: the hypothalamic-pituitary-adrenal axis and its actions. Ann N Y Acad Sci. 2014 May; 1318: 71-80. doi: 10.1111/nyas.12464

2. Charmandari E, Kino T, ChrousosGP. Neonatal and pediatric pharmacology Glucocorticoids. In Yaffe SJ, Aranda JV, 4th edn. 2010 eds. Philadelphia: Lippincott Williams and Wilkins; 76072.

3. Oelkers W. Adrenal insufficiency. N Engl J Med. 1996 Oct 17; 335(16): 1206-12.

4. Schmidt IL, Lahner H, Mann K, Petersenn S. Diagnosis of adrenalinsufficiency: Evaluation of the corticotropinreleasinghormonetest and Basalserumcortisol in comparison to the insulintolerancetest in patients with hypothalamicpituitary-adrenaldisease. J Clin EndocrinolMetab. 2003 Sep; 88[9] : 4193-8.

5. Al-Aridi R, Abdelmannan D, Arafah BM. Biochemical diagnosis of adrenal insufficiency: the added value of dehydroepiandrosterone sulfate measurements. EndocrPract. 2011 Mar-Apr; 17(2): 261-70. doi: 10.4158/EP10262.RA.

6. Nasrallah MP, Arafah BM. The value of dehydroepiandrosterone sulfate measurements in the assessment of adrenal function. J ClinEndocrinolMetab; 2003 88: 5293-98.

7. Arafah BM. Hypothalamic pituitary adrenal function during critical illness: limitations of current assessment methods. J Clin Endocrinol Metab. 2006 Oct; 91(10): 3725-45.

8. Kassem SL, El Sibai K, Chaiban J, Abdelmannan D, Arafah BM. Measurements of serum DHEA and DHEA sulphate levels improve the accuracy of the low-dose cosyntropin test in the diagnosis of central adrenal insufficiency. J ClinEndocrinolMetab. 2012 Oct; 97(10): 3655-62. doi: 10.1210/jc.2012-1806.

9. Arafah BM, Kailani SH, Nekl KE, Gold RS, Selman WR. Immediate recovery of pituitary function after transsphenoidal resection of pituitary macroadenomas. J Clin Endocrinol Metab. 1994 Aug; 79(2): 348-54.

10. Kazlauskaite R, Evans AT, Villabona CV, Abdu TA, Ambrosi $B$, Atkinson $A B$, Choi $C H$, et al. Consortium for Evaluation of Corticotropin Test in Hypothalamic-Pituitary Adrenal Insufficiency J ClinEndocrinolMetab. 2008 Nov; 93(11): 424553. doi: 10.1210/jc.2008-0710.

11. Dorin RI, Qualls CR, Crapo LM. Diagnosis of adrenal insufficiency Ann Intern Med. 2003 Aug 5; 139(3): 194-204.

12. Mayo Clinic is medical laboratories. Test ID: DHES. Available at http://www.mayomedicallaboratories.com/testcatalog/Clinical+and+Interpretive/8493. Acessed at May 2, 2015.

13. Mansour AA, Odaa AH, Wanoose HL. Corticosteroid nonprescription use: a cross-sectional hospital-based study in Basrah. Med PrincPract. 2010; 19(3): 182-7. doi: 10.1159/000285283. 
14. Jones SL, Trainer PJ, Perry L, Wass JA, Bessser GM, Grossman A. An audit of the insulin tolerance test in adult subjects in an acute investigation unit over one year. ClinEndocrinol (Oxf). 1994 Jul; 41(1): 123-8.

15. Shah A, Stanhope R, Matthew D. Hazards of pharmacological tests of growth hormone secretion in childhood. BMJ. 1992 Jan 18; 304(6820): 173-4

16. Crowley RK, Argese N, Tomlinson JW, Stewart PM. Central hypoadrenalism. J ClinEndocrinolMetab. 2014 Nov; 99(11): 4027-36. doi: 10.1210/jc.2014-2476.

17. Broersen LH, Pereira AM, Jørgensen JO, Dekkers OM. Adrenal Insufficiency in Corticosteroids Use: Systematic Review and Meta-Analysis. J ClinEndocrinolMetab. 2015 Jun; 100(6): 217180. doi: 10.1210/jc.2015-1218

18. Hahner S, Loeffler M, Bleicken B, Drechsler C, Milovanovic D, Fassnacht $\mathrm{M}$, et al. Epidemiology of adrenal crisis in chronic adrenal insufficiency: the needfor new prevention strategies. Eur J Endocrinol. 2010 Mar; 162(3): 597-602. doi: 10.1530/EJE09-0884.

19. Dorsey MJ, Cohen LE, Phipatanakul W, Denufrio D, Schneider LC. Assessment of adrenal suppression in children with asthma treated with inhaled corticosteroids: use of dehydroepiandrosterone sulfate as a screening test. Ann Allergy Asthma Immunol. 2006 Aug; 97(2): 182-6.

20. Maguire AM, Biesheuvel CJ, Ambler GR, Moore B, McLean M, Cowell CT. Evaluation of adrenal function using the human corticotrophin-releasing hormone test, low dose Synacthen test and 9am cortisol level in children and adolescents with central adrenal insufficiency. ClinEndocrinol (Oxf). 2008 May; 68(5): 683-91.

21. Usta MB, Tuncel OK, Akbas S, Aydin B, Say GN. Decreased dehydroepiandrosterone sulphate levels in adolescents with post-traumatic stress disorder after single sexual trauma. Nord J Psychiatry. 2015 Jul 15: 1-5.

22. Rothwell PM, Udwadia ZF, Lawler PG. Cortisol response to corticotropin and survival in septic shock. Lancet. 1991 Mar 9; 337(8741): 582-3.

23. Annane D, Sébille V, Troché G, Raphaël JC, Gajdos P, Bellissant E. A 3-level prognostic classification in septic shock based on cortisol levels and cortisol response to corticotropin. JAMA. 2000 Feb 23; 283(8): 1038-45.

24. Annane $D$, Sébille $V$, Charpentier C, Bollaert PE, François $B$, Korach JM, et al. Effect of treatment with low doses of hydrocortisone and fludrocortisone on mortality in patients with septic shock. JAMA. 2002 Aug 21; 288(7): 862-71.

25. Cooper MS, Stewart PM. Corticosteroid insufficiency in acutely ill patients. N Engl J Med. 2003 Feb 20; 348(8): 727-34.

26. Boonen E, Bornstein SR, Van den Berghe G. New insights into the controversy of adrenal function during critical illness. Lancet Diabetes Endocrinol. 2015 Jun 10. pii: S2213-8587(15)00224-7. doi: 10.1016/S2213-8587(15)00224-7.
27. Ferrante E, Morelli V, Giavoli C, Mantovani G, Verrua E, Sala E, et al. Is the 250- $\mu \mathrm{g}$ ACTH test a useful tool for the diagnosis of centralhypoadrenalism in adult patients with pituitary disorders? Hormones (Athens). 2012 Oct-Dec; 11(4): 428-35.

28. Yamaji T, Ishibashi M, Takaku F, Itabashi $A$, Katayama S, Ishii J. Serum dehydroepiandrosterone sulfate concentrations in secondary adrenal insufficiency. JClin EndocrinolMetab. 1987 Sep; 65(3): 448-51.

29. Oelkers W. Dose-response aspects in the clinical assessment of the hypothalamo-pituitary-adrenal axis, and the low-dose adrenocorticotropintest. Eur J Endocrinol. 1996 Jul; 135(1): 2733.

\section{Comment on this article:}

\section{(f) in $8+\mathbf{S}$ ?}

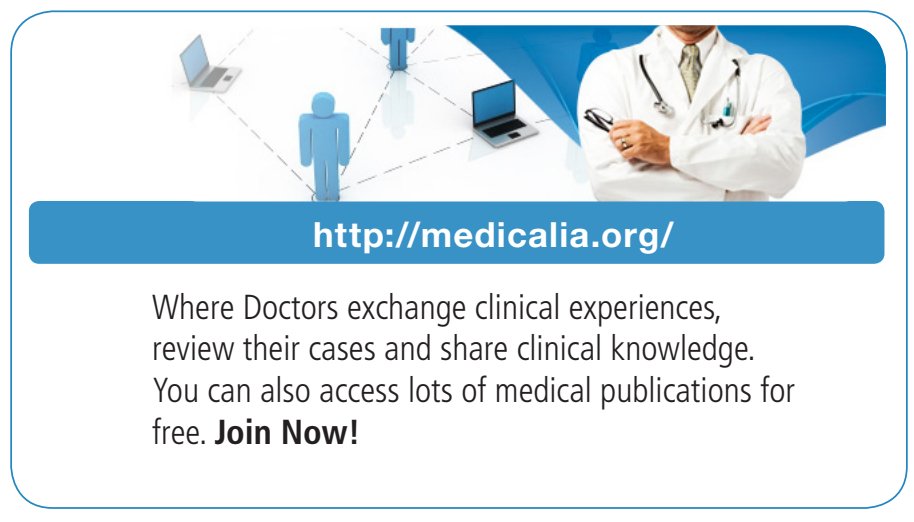

Publish with iMedPub

http://www.imed.pub

International Archives of Medicine is an open access journal publishing articles encompassing all aspects of medical science and clinical practice. IAM is considered a megajournal with independent sections on all areas of medicine. IAM is a really international journal with authors and board members from all around the world. The journal is widely indexed and classified Q1 in category Medicine. 